\title{
ADMINISTRASI PELAYANAN KARTU KUNING (AK 1) PADA DINAS TENAGA KERJA DAN TRANSMIGRASI
}

\author{
Aida Fitriani \\ Fakultas Ilmu Sosial dan Ilmu Politik Universitas Kapuas Sintang \\ Jln. Oevang Oeray Nomor 92 Baning Kota Sintang \\ Email: aidafitriani45@gmail.com
}

\begin{abstract}
Abstrak: Perkembangan penduduk yang cukup pesat merupakan satu fenomena yang menjadi perhatian serius Pemerintah Pusat maupun Pemerintah Daerah. Permasalahan ketenagakerjaan yang dihadapi di Kabupaten Sintang antara lain: (1) Jumlah angkatan kerja dan angka pengangguran yang tinggi (2) Rendahnya kualitas dan produktivitas tenaga kerja yang siap bersaing dalam memasuki pasar kerja, (3) Rendahnya sumber daya manusia dalam menghadapi pasar global di bidang ketenagakerjaan, (4) Kurangnya lapangan kerja yang dapat menampung dan menyalurkan angkatan kerja saat ini, (5) Rendahnya potensi masyarakat, baik ekonomi maupun sosial dalam menghadapi perubahan global, (7) Luas wilayah, jumlah penduduk yang besar dan penyebaran penduduk yang tidak merata serta banyaknya tenaga kerja yang kurang terampil, (8) Kurangnya sarana latihan kerja yang dipergunakan untuk penyelenggaraan pelatihan bagi tenaga kerja. Pelayanan publik yang berkaitan dengan persoalan ini menjadi semakin penting, karena senantiasa berhubungan dengan khalayak masyarakat ramai yang memiliki keaneka ragaman kepentingan dan tujuan.
\end{abstract}

Kata Kunci: Administrasi Ketenagakerjaan, Pelayanan Publik

Angkatan kerja merupakan faktor penting dalam proses produksi, yaitu sebagai sarana produksi, tenaga kerja lebih penting dari pada sarana produksi yang lainnya, seperti; bahan mentah, tanah, air dan sebagainya. Karena manusia lah yang menggerakkan semua sumber-sumber tersebut untuk menghasilkan barang. Penduduk usia kerja biasanya dikelompokkan ke dalam angkatan kerja dan bukan angkatan kerja. Konsep ini diadopsi dari negara yang sudah maju yang mempunyai ciri-ciri ekonomi dan tenaga kerja yang berbeda dengan negara yang sedang berkembang serta pertumbuhan ekonominya stabil. Selain itu penyediaan tenaga kerja yang sifatnya terbatas karena tidak semua penduduk merupakan angkatan kerja, dalam hal ini hanya penduduk yang telah mencapai usia minimum tertentu baru dianggap sebagai tenaga kerja potensial atau angkatan kerja, serta statusnya tidak sebagai mengurus rumah tangga, sekolah, dan lainnya. Di Indonesia misalnya, hanya mereka yang telah mencapai usia 10 tahun ke atas baru dianggap sebagai angkatan kerja.

Selain itu, tidak semua usia kerja terlibat dalam kegiatan ekonomi (bekerja) seperti yang telah diuraikan di atas. Sehingga jumlah angkatan kerja dalam suatu daerah pada suatu kurun waktu tertentu tergantung dari jumlah penduduk usia kerja, semakin besar jumlah penduduk usia kerja, maka akan cenderung semakin besar jumlah angkatan kerja. Ketenagakerjaan merupakan salah satu sektor penting bagi pembangunan ekonomi Nasional dan khususnya dalam upaya pemerintah untuk mengurangi jumlah penduduk miskin. Dengan menciptakan dan menerapkan pelbagai program pembangunan pada sektor ekonomi dan sektor ketenagakerjaan pada kelompok penduduk yang tergolong miskin; sehingga kelompok tersebut diharapkan dapat meningkatkan pendapatan yang sekaligus akan meningkatkan kesejahteraannya.

Substansi pelayanan publik selalu dikaitkan dengan suatu kegiatan yang dilakukan oleh seseorang atau kelompok orang atau instansi tertentu untuk memberikan bantuan dan kemudahan kepada masyarakat dalam rangka mencapai tujuan tertentu. Oleh karena itu institusi pelayanan publik dapat dilakukan oleh pemerintah maupun non-pemerintah. Jika pemerintah, maka organisasi birokrasi pemerintahan merupakan organisasi terdepan yang berhubungan dengan pelayanan publik. Dan jika non-pemerintah, maka dapat berbentuk organisasi partai politik, organisasi keagamaan, lembaga swadaya masyarakat maupun organisasi-organisasi kemasyarakatan yang lain. Siapapun bentuk institusi pelayanananya, maka yang terpenting adalah bagaimana memberikan bantuan dan kemudahan kepada masyarakat dalam rangka memenuhi kebutuhan dan kepentingannya. Menurut Suryono (2009:4) guna menanggulangi kesan buruk birokrasi seperti itu, birokrasi perlu melakukan beberapa perubahan sikap dan perilakunya antara lain: Birokrasi harus lebih mengutamakan sifat pendekatan tugas yang diarahkan pada hal pengayoman dan pelayanan masyarakat; dan menghindarkan kesan pendekatan kekuasaan dan kewenangan.

Birokrasi perlu melakukan penyempurnaan organisasi yang bercirikan organisasi modern, ramping, efektif dan efesien yang mampu membedakan antara tugas-tugas yang perlu 
ditangani dan yang tidak perlu ditangani (termasuk membagi tugas-tugas yang dapat diserahkan kepada masyarakat). Birokrasi harus mampu dan mau melakukan perubahan sistem dan prosedur kerjanya yang lebih berorientasi pada ciri-ciri organisasi modern yakni: pelayanan cepat, tepat, akurat, terbuka dengan tetap mempertahankan kualitas, efesiensi biaya dan ketepatan waktu. Birokrasi harus memposisikan diri sebagai fasilitator pelayan publik dari pada sebagai agen pembaharu (change of agent) pembangunan. Birokrasi harus mampu dan mau melakukan transformasi diri dari birokrasi yang kinerjanya kaku (rigid) menjadi organisasi birokrasi yang strukturnya lebih desentralistis, inovatif, flrksibel dan responsif. Dari pandangan tersebut di atas, dapat disimpulkan bahwa organisasi birokrrasi yang mampu memberikan pelayanan publik secara efektif dan efesien kepada masyarakat, salah satunya jika strukturnya lebih terdesentralisasi daripada tersentralisasi. Sebab, dengan struktur yang terdesentralisasi diharapkan akan lebih mudah mengantisipasi kebutuhan dan kepentingan yang diperlukan oleh masyarakat, sehingga dengan cepat birokrasi dapat menyediakan pelayanannya sesuai yang diharapkan masyarakat pelanggannya. Sedangkan dalam kontek persyaratan budaya organisasi birokrasi, menurut Suryono (2009:4) "perlu dipersiapkan tenaga kerja atau aparat yang benar-benar memiliki kemampuan (capabelity), memiliki loyalitas kepentingan (competency), dan memiliki keterkaitan kepentingan (consistency atau coherency)".

Dalam tinjauan manajemen pelayanan publik, Moenir (1998:23) menyatakan ciri struktur birokrasi yang terdesentralisir memiliki beberapa tujuan dan manfaat antara lain : Mengurangi (bahkan menghilangkan) kesenjangan peran antara organisasi pusat dengan organisasi-organisasi pelaksana yang ada dilapangan. Melakukan efesiensi dan penghematan alokasi penggunaan keuangan. Mengurangi jumlah staf/aparat yang berlebihan terutama pada level atas dan level menengah (prinsip rasionalisasi). Mendekatkan birokrasi dengan masyarakat pelanggan. Mencermati pandangan ini, maka dalam kontek pelayanan publik dapat digaris bawahi bahwa keberhasilan proses pelayanan publik sangat tergantung pada dua pihak yaitu birokrasi (pelayan) dan masyarakat (yang dilayani). Dengan demikian menurut Suryono (2009:6) untuk melihat kualitas pelayanan publik perlu diperhatikan dan dikaji dua aspek pokok yakni : "Pertama, aspek proses internal organisasi birokrasi (pelayan); Kedua, aspek eksternal organisasi yakni kemanfaatan yang dirasakan oleh masyarakat pelanggan".

Dalam hal ini Islamy (1999: 23) menyebut beberapa prinsip pokok yang harus dipahami oleh aparat birokrasi publik dalam aspek internal organisasi yaitu :
Prinsip Aksestabelitas, dimana setiap jenis pelayanan harus dapat dijangkau secara mudah oleh setiap pengguna pelayanan (misal: masalah tempat, jarak dan prosedur pelayanan). Prinsip Kontinuitas, yaitu bahwa setiap jenis pelayanan harus secara terus menerus tersedia bagi masyarakat dengan kepastian dan kejelasan ketentuan yang berlaku bagi proses pelayanan tersebut. Prinsip Teknikalitas, yaitu bahwa setiap jenis pelayanan proses pelayanannya harus ditangani oleh aparat yang benar-benar memahami secara teknis pelayanan tersebut berdasarkan kejelasan, ketepatan dan kemantapan sistem, prosedur dan instrumen pelayanan. Prinsip Profitabilitas, yaitu bahwa proses pelayanan pada akhirnya harus dapat dilaksanakan secara efektif dan efesien serta memberikan keuntungan ekonomis dan sosial baik bagi pemerintah maupun bagi masyarakat luas. Prinsip Akuntabilitas, yaitu bahwa proses, produk dan mutu pelayanan yang telah diberikan harus dapat dipertanggung jawabkan kepada masyarakat karena aparat pemerintah itu pada hakekatnya mempunyai tugas memberikan pelayanan yang sebaik-baiknya kepada masyarakat.

Begitu pentingnya profesionalisasi pelayanan publik ini, pemerintah melalui Menteri Negara Pendayagunaan Aparatur Negara telah mengeluarkan suatu kebijaksanaan Nomor 81 Tahun 1993 tentang Pedoman Tatalaksana Pelayanan Umum yang perlu dipedomani oleh setiap birokrasi publik dalam memberikan pelayanan kepada masyarakat berdasar prinsipprinsip pelayanan sebagai berikut:

Kesederhanaan, dalam arti bahwa prosedur dan tata cara pelayanan perlu ditetapkan dan dilaksanakan secara mudah, lancar, cepat, tepat, tidak berbelit-belit, mudah dipahami dan mudah dilaksanakan oleh masyarakat yang meminta pelayanan. Kejelasan dan kepastian, dalam arti adanya kejelasan dan kepastian dalam hal prosedur dan tata cara pelayanan, persyaratan pelayanan baik teknis maupun administratif, unit kerja pejabat yang berwenang dan bertanggung jawab dalam meberikan pelayanan, rincian biaya atau tarif pelayanan dan tata cara pembayaran, dan jangka waktu penyelesaian pelayanan. Keamanan, dalam arti adanya proses dan produk hasil pelayanan yang dapat memberikan keamanan, kenyamanan dan kepastian hukum bagi masyarakat. Keterbukaan, dalam arti bahwa prosedur dan tata cara pelayanan, persyaratan, unit kerja pejabat penanggung jawab pemberi pelayanan, waktu penyelesaian, rincian biaya atau tarif serta hal-hal lain yang berkaitan dengan proses pelayanan wajib diinformasikan secara terbuka agar mudah diketahui dan dipahami oleh masyarakat, baik diminta maupun tidak diminta. Efesiensi, dalam arti bahwa persyaratan pelayanan hanya dibatasi pada hal-hal yang berkaitan langsung dengan pencapaian sasaran pelayanan dengan tetap memperhatikan 
keterpaduan antara persyaratan dengan produk pelayanan. Ekonomis, dalam arti bahwa pengenaan biaya atau tarif pelayanan harus ditetapkan secara wajar dengan memperhatikan: nilai barang dan jasa pelayanan, kemampuan masyarakat untuk membayar, dan ketentuan perundang-undangan yang berlaku. Keadilan dan Pemerataan, yang dimaksudkan agar jangkauan pelayanan diusahakan seluas mungkin dengan distribusi yang merata dan adil bagi seluruh lapisan masyarakat. Ketepatan Waktu, dalam arti bahwa pelaksanaan pelayanan harus dapat diselesaikan tepat pada waktu yang telah ditentukan.

Oleh karena itu dalam merespon prinsipprinsip pelayanan publik yang perlu dipedomani oleh segenap aparat birokrasi peleyanan publik , maka kiranya harus disertai pula oleh sikap dan perilaku yang santun, keramah tamahan dari aparat pelayanan publik baik dalam cara menyampaikan sesuatu yang berkaitan dengan proses pelayanan maupun dalam hal ketapatan waktu pelayanan. Hal ini dimungkinkan agar layanan tersebut dapat memuaskan orang-orang atau kelompok orang yang dilayani. Menurut Suryono (2009:12) ada 4 (empat) kemungkinan yang terjadi dalam mengukur kepuasan dan kualitas pelayanan publik ini, yaitu : (1) Bisa jadi pihak aparat birokrasi yang melayani dan pihak masyarakat yang dilayani sama-sama dapat dengan mudah memahami kualitas pelayanan tersebut (mutual knowledge), (2) Bisa jadi pihak aparat birokrasi yang melayani lebih mudah memahami dan mengevaluasi kualitas pelayanan publik daripada masyarakat pelanggan yang dilayani (producer knowledge), (3) Bisa jadi masyarakat pelanggan yang dilayani lebih mudah dan lebih memahami dalam mengevaluasi kualitas pelayanan yang diberikan oleh aparat birokrasi pelayanan publik (consumer knowledge), dan (4) Bisa jadi baik aparat birokrasi pelayanan publik maupun masyarakat yang dilayani sama-sama tidak tahu dan mendapat kesulitan dalam mengevaluasi kualitas pelayanan publik (mutual Ignorance).

Menurut FredLuthans (dalam Suryono, 2009:5) "dalam hal ini teori analisa yang dapat dipergunakan antara lain teori "Impression Management" yaitu bagaimana mengukur tingkat responsif, tingkat responsibility dan tingkat representatif seseorang atau kelompok orang terhadap fenomena tertentu". Sayangnya, dalam praktek dan tinjauan teoritis untuk menentukan tolok ukur kualitas pelayanan publik tidak semudah membalikkan telapak tangan. Steers (dalam Suryono, 2009:8) menyebutkan beberapa faktor yang berkepentingan dalam upaya mengidentifikasi kualitas pelayanan publik antara lain : "variabel karakteristik organisasi, variabel karakteristik lingkungan, variabel karakteristik pekerja/aparat, variabel karakteristik kebijaksanaan, dan variabel parkatek-praktek manajemennya". Untuk melengkapi pendapat ini, maka Effendi (1993:25) menyebutkan beberapa faktor lagi yang menyebabkan rendahnya kualitas pelayanan publik (di Indonesia) antara lain adanya: Konteks monopolistik, dalam hal ini karena tidak adanya kompetisi dari penyelenggara pelayanan publik non pemerintah, tidak ada dorongan yang kuat untuk meningkatkan jumlah, kualitas maupun pemerataan pelayanan tersebut oleh pemerintah. Tekanan dari lingkungan, dimana faktor lingkungan amat mempengaruhi kinerja organisasi pelayanan dalam transaksi dan interaksinya antara lingkungan dengan organisasi publik. Budaya patrimonial, dimana budaya organisasi penyelenggara pelayanan publik di Indonesia masih banyak terikat oleh tradisi-tradisi politik dan budaya masyarakat setempat yang seringkali tidak kondusif dan melanggar peraturanperaturan yang telah ditentukan.

Untuk solusinya dalam menghadapi tantangan dan kendala-kendala pelayanan publik sebagaimana disebutkan di atas, menurut Suryono (2009:11) diperlukan adanya langkah-langkah strategis antara lain; Merubah tekanan-tekanan sistem pemerintahan yang sifatnya sentralistik otoriter menjadi sistem pemerintahan desentralistik demokratis; Kedua: Membentuk asosiasi/ perserikatan kerja dalam pelayanan publik; Ketiga: Meningkatkan keterlibatan masyarakat, baik dalam perumusan kebijakan pelayanan publik, proses pelaksanaan pelayanan publik maupun dalam monitoring dan pengawasan pelaksanaan pelayanan publik; Keempat : Adanya kesadaran perubahan sikap dan perilaku dari aparat birokrasi pelayanan publik menuju model birokrasi yang lebih humanis (Post weberian);Kelima : Menyadari adanya pengaruh kuat perkembangan dan kemajuan ilmu pengetahuan dan teknologi dalam menunjang efektivitas kualitas pelayanan publik; Keenam:Pentingnya faktor aturan dan perundangundangan yang menjadi landasan kerja bagi aparat pelayanan publik; Ketujuh: Pentingnya perhatian terhadap faktor pendapatan dan penghasilan (wages and salary) yang dapat memenuhi kebutuhan minimum bagi aparat pelayanan publik; Kedelapan: Pentingnya faktor keterampilan dan keahlian petugas pelayanan publik; Kesembilan:Pentingnya faktor sarana phisik pelayanan publik; Kesepuluh : Adanya saling pengertian dan pemahaman bersama (mutual understanding) antara pihak aparat birokrasi pelayan publik dan masyarakat yang memerlukan pelayanan untuk mematuhi peraturan dan perundang-undangan yang berlaku khususnya dalam pelayanan publik.

Sutopo dan Sugiyanti (1998:62) menyatakan "titik awal dari siklus pengembangan pelayanan adalah pembaharuan disain". Yang dimaksud pembaharuan disain tidak selalu harus menciptakan yang baru sama sekali. Pelayanan yang sudah ada secara berkala juga memerlukan 
pembaharuan agar semakin dapat memenuhi kebutuhan pelanggan. Kebutuhan untuk menciptakan pelayanan yang baru sama sekali biasanya terjadi karena perubahan yang mendasar pada tingkat visi dan misi organisasi, sehingga dirasa perlu menyesuaikan tugas pokok dan fungsi unit-unit dalam organisasi bersangkutan. Menurut Sutopo dan Sugiyanti (1998:63) "proses pembaharuan disain pelayanan melibatkan beberapa langkah kegiatan: (1) menemukan roh pelayanan, (2) menetapkan jenis pelayanan, (3) menghayati kegiatan pelanggan, serta (4) merancang proses pelayanan". Pelayanan prima hanya akan berhenti sebagai angan-angan saja, jika diterapkan secara nyata dalam penyelenggaraan sehari-hari pada setiap jenis pelayanan. Aplikasi pelayanan prima bukanlah hal yang mudah, karena membutuhkan tingkat kesungguhan (komitmen), penguasaan, dan konsistensi tindakan yang sangat tinggi.

Komitmen untuk sungguh-sungguh menyelenggarakan pelayanan prima tentu bersifat sangat pribadi. Hanya diri kita sendiri yang dapat mengetahui, menilai, mengukur dan membangkitkannya. Namun demikian, pengalaman lapangan menunjukkan bahwa komitmen selain memang merupakan prasyarat untuk keberhasilan pelayanan prima, tetapi sekaligus juga merupakan salah satu hasil utama dari penyelenggaraan pelayanan yang prima. Setiap kali kita melaksanakan pelayanan, akan diperoleh rasa kepuasan sampai pada kadar tertentu. Pengalaman lapangan menunjukkan bahwa upaya mewujudkan pelayanan prima sungguh memerlukan waktu dan perhatian. Karena organisasi kita, dan juga masyarakat yang kita layani selalu tumbuh dan berkembang secara dinamis, maka aplikasi pelayanan prima akan lebih tepat jika kita simka sebagai sebuah proses pembelajaran organisasi yang tak berkesudahan. Sebuah pencairan tanpa henti terhadap wujud nyata dari apa yang kita pahami sebagai prima (yang terbaik). Dilihat sebagai proses belajar, aplikasi pelayanan prima merupakan upaya perbaikan secara bertahap, dan berkelanjutan. Langkah-langkah perbaikannya perlu dilakukan dengan mengikuti siklus pengembangan pelayanan. Jika siklus ini diulangulang secara teratur dari waktu ke waktu, maka akan menghasilkan semacam alur spiral dari sejarah perkembangan sebuah pelayanan, menuju bentuknya yang semakin hari menjadi semakin prima.

Sutopo dan Sugiyanti (1998:67) menyatakan "standar pelayanan merupakan dokumentasi resmi yang berisi rincian teknis dari sebuah sistem pelayan". Standar pelayanan berguna sebagai pedoman kerja dari batasan mutu pelayanan yang harus dipenuhi oleh para pelaksana. Sedangan bagi para pelanggan kita standar pelayanan berguna sebagai jaminan mutu pelayanan yang seharusnya mereka peroleh. Menurut Sutopo dan Sugiyanti (1998:67) "standar pelayanan umumnya memuat hal-hal seperti berikut: Visi dan Misi Pelayanan, Jenis Pelayanan yang ditawarkan, Spesifikasi Pelanggan, Prosedur Pelayanan, Pengawasan dan Pengendalian Mutu, Lampiran yang memuat Denah Lokasi, Formulir, Hasil Kesepakatan, dan sebagainya". Sampai saat ini telah ditawarkan berbagai ukuran bagi standar pelayanan, dengan titik pusat penilaian yang saling berbeda, dan cara pengukuran yang beraneka ragam pula. Menurut Sutopo dan Sugiyanti (1998:36) namun demikian, terdapat beberapa kesamaan standar pelayanan yang sering dijumpai di berbagai bidang kajian, yaitu: Proses pelayanan dilaksanakan sesuai prosedur pelayanan yang standar. Petugas pelayanan memiliki kompetensi yang diperlukan. Pelaksanaan pelayanan didukung tekonologi, sarana, dan prasarana yang memadai. Pelayanan dilaksanakan dengan cara-cara yang tidak bertentangan dengan kode etik. Pelaksanaan pelayanan dapat memuaskan pelanggan. Pelaksanaan pelayanan dapat memuaskan petugas pelayanan. Pelaksanaan pelayanan mendatangkan keuntungan bagi lembaga penyedia pelayanan.

Standar pelayanan merupakan aplikasi dari rancangan proses pelayanan dalam bentuk dokumentasi tertulis. Standar harus ditulis dengan cermat, rapi, dan menyeluruh. Bagi petugas pelayanan standar ini berlaku sebagai pedoman kerja dan baku mutu yang harus dipenuhi. Sedangkan bagi pelanggan standar ini memuat jaminan mutu pelayanan yang selayaknya akan mereka dapatkan. Pada umumnya standar pelayanan memuat visi dan misi pelayanan, jenisjenis pelayanan yang ditawarkan, spesifikasi pelanggan, prosedur pelayanan, pengawasan dan pengendalian mutu, serta berbagai lampiran yang diperlukan.

Menurur Dunn (2000:608) "istilah evaluasi mempunyai arti yang berhubungan di mana masingmasing menunjuk pada aplikasi beberapa skala nilai terhadap hasil kebijakan dan program. Secara umum istilah evaluasi dapat disamakan dengan penaksiran (appraisal), pemberian angka (rating), dan penilaian (assegment) yaitu kata-kata yang menyatakan usaha untuk menganalisis hasil kebijakan dalam arti satuan nilainya". Dalam arti yang lebih spesifik evaluasi berkenaan dengan produksi informasi mengenai manfaat hasil kebijakan. Dalam hal ini dapat dikatakan bahwa kebijakan atau program telah mencapai tingkat kinerja yang bermakna. Konsep dasar evaluasi didasarkan pada klasifikasi responsibilitas manajerial pada tiap tingkatan dalam organisasi yang bertujuan untuk pelaksanaan kegiatan pada tiap bagian. Masing-masing individu pada tiap klasifikasi bertanggung jawab atas setiap kegiatan yang dilaksanakan pada bagiannya. "Konsep inilah yang membedakan adanya kegiatan-kegiatan yang 
terkendali (controllable activities) dan kegiatankegiatan yang tidak terkendali (uncontrol-lable activities)". (Pusdiklatwas BPKP, 2000:5). Evaluasi suatu proyek atau kegiatan pada dasarnya adalah suatu pemeriksaan secara sistematis terhadap masa lampau yang akan digunakan untuk meramalkan, memperhitungkan dan mengendalikan hari depan secara lebih baik. Dengan demikian evaluasi lebih bersifat melihat ke depan daripada mencari kesalahan-kesalahan di masa lalu dan diarahkan pada upaya peningkatan kesempatan demi keberhasilan tujuan kegiatan. Atau dengan kata lain tujuan evaluasi adalah untuk penyempurnaan kegiatan di masa mendatang. Berdasarkan pada waktu pelaksanaannya terdapat dua macam evaluasi (Dipohusodo, 1996:64), yaitu "evaluasi summatif yang dilakukan setelah kegiatan berakhir dan evaluasi formatif dilaksanakan pada saat kegiatan/proyek sedang berjalan". Evaluasi summatif bermanfaat untuk digunakan merumuskan kebijaksanaan dan perencanaan kegiatan/proyek-proyek serupa lainnya di masa mendatang. Evaluasi formatif digunakan untuk keperluan penyesuaian dan perencanaan ulang atas kegiatan/proyek yang sedang berjalan. Perencanaan evaluasi harus sudah dipertimbangkan pada saat menyusun daftar kegiatan yang akan dilaksanakan dan paling lambat disiapkan pada tahap-tahap awal pelaksanaan. Dengan mempertimbangkan kebutuhan - kebutuhan evaluasi secara lebih dini berarti penyusunan logika proyek berlangsung lebih realistis, sehingga dapat menentukan informasi dan menyiapkan data-data indikator yang diperlukan. Karena untuk dapat mengevaluasi sesuatu proyek harus berlandaskan pada pengertian apa yang diharapkan dapat dicapai oleh proyek, sehingga dengan sendirinya harus menggunakan perangkat kerangka logis untuk itu. Dalam hal ini hendaknya dicatat, bahwa sesungguhnya setiap proyek selalu sudah memiliki kerangka logis baik yang terwujud sebagai dokumen tertulis maupun tidak, atau sudah berhasil menunjukkan suatu urutan logika maupun belum. Karena layak atau tidak sekalipun, tentunya sesuatu proyek dilaksanakan demi untuk mencapai tujuan tertentu. Meskipun begitu, seandainya untuk mengevaluasi suatu proyek tidak tersedia kerangka logis ataupun dokumen yang dapat dipakai sebagai penggantinya, maka perencanaan evaluasi dapat dimulai dengan bertanggung jawab dan terlibat di dalam proses penyusunannya ialah para perencana, pelaksana, dan pengawas proyek. Apabila hasil dan langkah-langkah terdahulu belum mendorong kita untuk melakukan Pembaharuan Disain, maka tiba saatnya harus dilakukan Evaluasi terhadap Pelayanan kita. Titik perhatian kita dalam Langkah Evaluasi ini hanya satu, yaitu Mengukur dan Menilai Manfaat Pelayanan kita dalam memberdayakan Masyarakat Pelanggan. Evaluasi Pelayanan diperlukan untuk menilai apakah
Pelayanan kita sudah sesuai dengan Harapan Pelanggan atau belum. Metodologi yang digunakan adalah dengan Memanfaatkan SQGM (Service Quality Gap Model). Model ini akan membimbing kita untuk secara Sistematis menemukan titik-titik paling lemah dalam Siklus Pengembangan Pelayanan, sehingga telah menyebakan Harapan Pelanggan tidak terpenuhi. Pelayanan publik menurut Undang-undang Nomor 25 Tahun 2009 tentang Pelayanan Publik adalah kegiatan atau rangkaian kegiatan dalam rangka pemenuhan kebutuhan pelayanan sesuai dengan peraturan perundang-undangan bagi setiap warga negara dan penduduk atas barang jasa, dan/atau pelayanan administratif yang disediakan oleh penyelenggara pelayanan publik.

Ridwan (2009:11), dalam rangka mewujudkan pelayanan prima dan berkualitas yang berorientasi pada kepuasan pelanggan (customerdriven governance) memiliki ciri-ciri; (a) lebih memfokuskan diri kepada fungsi pengaturan, melalui berbagai kebijakan yang memfasilitasi berkembangnya kondisi yang kondusif bagi kegiatan pelayanan oleh masyarakat; (b) lebih memfokuskan diri pada pemberdayaan masyarakat, sehingga masyarakat mempunyai rasa memiliki yang tinggi terhadap fasilitas pelayanan yang telah dibangun bersama; (c) menerapkan sistem kompetisi dalam hal penyediaan pelayanan publik tertentu, sehingga masyarakat memperoleh pelayanan yang berkualitas; (d) terfokus pada pencapaian dengan visi, misi, tujuan, dan sasaran berorientasi pada hasil (outcomes) yang sesuai dengan input yang digunakan; (e) lebih mengutamakan apa yang diinginkan oleh masyarakat; (f) pada hal tertentu, pemerintah juga berperan untuk memperoleh pendapat dari pelayanan yang dilaksanakan; (g) lebih mengutamakan antisipasi terhadap permasalahan pelayanan; (h) lebih mengutamakan desentralisasi dalam pelaksanaan pelayanan; (i) menerapkan sistem pasar dalam memberikan pelayanan. Selanjutnya menurut Mohammad dalam (Hermansyah,2007:93) dinyatakan pelayanan publik juga memiliki beberapa sifat antara lain: (1) memiliki dasar hukum yang jelas dalam penyelenggaraannya, (2) memiliki wide stakeholder, (3) memiliki tujuan sosial, (4) dituntut akuntabel kepada publik, (5) memiliki complex and debate performance indicators serta (6) seringkali menjadi sasaran isu politik. Pada dasarnya pemerintah telah melakukan berbagai upaya untuk dapat menghasilkan pelayanan yang cepat, tepat, manusiawi, murah tidak diskriminatif dan transparan, hal ini ditandai dengan adanya kebijakan yang berhubungan dengan pelayanan publik salah satunya adalah penetapan tentang standar pelayanan minimum (SPM). Standar pelayanan yang ditetapkan menurut Ridwan (2009:12) mempunyai tujuan: (a).menjadi alat 
monitoring dan analisis terhadap kinerja pelayanan sesuai dengan sasaran yang telah ditetapkan; (b). menjadi alat komunikasi yamg efektif anatara masyarakat pelanggan dengan penyedia langganan; (c). memberikan fokus yang jelas; (d). memberikan informasi mengenai akuntabilitas pelayanan yang harus dipertanggung jawabkan oleh penyedia layanan; dan (e). menjadi alat bagi pengambilan keputusan."

Berdasarkan hasil survey yang dilakukan UGM (dalam Sudrajat, 2006), menjelaskan bahwa "secara umum stakeholder menilai bahwa kualitas pelayanan publik mengalami perbaikan setelah diberlakukan otonomi daerah; namun dilihat dari sisi efisiensi dan efektifitas, responsivitas, kesamaan perlakuan masih jauh dari yang diharapkan dan masih memiliki berbagai kelemahan". Selanjutnya menurut Mohamad (2003) pelayanan publik masih memiliki berbagai kelemahan, antara lain : Kurang responsif. Kondisi ini terjadi pada hampir semua tingkatan unsure pelayanan, mulai dari tingkatan petugas pelayanan (front line) sampai dengan tingkatan penanggung jawab instansi. Respon terhadap berbagai keluhan, aspirasi, maupun harapan masyarakat seringkali lambat atau bahkan diabaikan sama sekali. Kurang informatif. Berbagai informasi yang seharusnya disampaikan kepada masyarakat, lambat atau bahkan tidak disampaikan kepada masyarakat. Kurang accessible.

Berbagai unit pelaksana pelayanan jauh dari jangkauan masyarakat, sehingga menyulitkan bagi mereka yang memerlukan pelayanan tersebut. Kurang koordinasi. Berbagai unit pelayanan yang terkait satu sama lainnya kurang berkoordinasi. Akibatnya sering terjadi tumpang tindih atau pertentangan kebijakan antara satu instansi pelayanan dengan instansi pelayanan lain yang terkait. Birokratis. Pelayanan (khususnya pelayanan perijinan) pada umumnya dilakukan dengan melalui proses yang terdiri dari berbagai level, sehingga menyebabkan penyelesaian pelayanan yang terlalu lama. Dalam kaitan dengan penyelesaian masalah pelayanan, kemungkinan staf pelayanan untuk dapat menyelesaikan masalah sangat kecil, dan di lain pihak kemungkinan masyarakat untuk bertemu dengan penanggungjawab pelayanan, dalam rangka menyelesaikan masalah yang terjadi ketika pelayanan diberikan, juga sangat sulit. Akibatnya, berbagai masalah pelayanan memerlukan waktu yang lama untuk diselesaikan. Kurang mau mendengarkan keluhan/saran/aspirasi masyarakat. Pada umumnya aparat pelayanan kurang memiliki kemauan untuk mendengar aspirasi dari masyarakat. Akibatnya pelayanan dilaksanakan dengan apa adanya, tanpa ada perbaikan dari waktu ke waktu. Inefisien. Berbagai persyaratan yang diperlukan (khususnya dalam pelayanan perijinan) seringkali tidak relevan dengan pelayanan yang diberikan.

\section{METODE}

Dilihat dari substansinya, penelitian ini pada dasarnya adalah menggunakan jenis penelitian deskriptif. penelitian deskriptif adalah "suatu penelitian yang hendak melakukan penilaian tentang sesuatu hal dengan tujuan untuk memperoleh gambaran secara sistematik, faktual dan akurat mengenai fakta-fakta serta hubungannya antar fakta". Berdasarkan pendapat tersebut, diketahui bahwa penelitian deskriptif bertujuan menggambarkan secara sistematik dan akurat fakta dan karakteristik mengenai sasaran atau mengenai bidang tertentu, serta berusaha menggambarkan situasi atau kejadian yang nyata. Informan penelitian adalah Kepala Dinas Tenaga Kerja Dan Transmigrasi Kabupaten Sintang. Kepala Bidang Tenaga Kerja Dinas Sosial, Tenaga Kerja Dan Transmigrasi Kabupaten Sintang.Kepala Seksi Pelatihan, Produktivitas dan Penempatan, Perluasan dan Tenaga Kerja. Kepala Seksi Hubungan Industrial dan Syarat Kerja. Kepala Seksi Pengawasan Tenaga Kerja. Para pencari kerja yang mendapatkan pelayanan Kartu Kuning (AK 1) pada Dinas Tenaga Kerja Dan Transmigrasi Kabupaten Sintang. Para pencari kerja tersebut dilklasifikasikan menurut tingkat pendidikan yaitu: jenjang pendidikan SMA, Diploma dan Sarjana. Teknik pengumpulan data yang akan dilakukan dalam penelitian ini adalah wawancara, observasi dan Studi dokumentasi. Pengolahan dan analisis data yang digunakan yaitu teknik analisis kualitatif. Penelitian ini berlokasi pada Dinas Tenaga Kerja Dan Transmigrasi Kabupaten Sintang.

\section{HASIL PENELITIAN DAN PEMBAHASAN}

Dalam upaya memecahkan persoalan di bidang ketenagakerjaan, Pemerintah Kabupaten Sintang telah menyusun berbagai kebijakan dan program ketenagakerjaan. Kebijakan dan program ketenagakerjaan tersebut merupakan penjabaran dari salah satu misi Kabupaten Sintang yaitu "memberdayakan masyarakat untuk memacu kemandirian dan partisipasi" dengan tujuan utama menciptakan pemerataan kesempatan kerja. Oleh karena itu, masalah ketenagakerjaan, yakni pengganguran merupakan masalah utama. Pemerintah mengalami banyak tekanan untuk segera berbenah diri, khususnya di bidang pelayanan Kartu Kuning (AK1) Kartu Kuning (AK 1). Pemerintah dinilai akuntabel apabila sanggup memberikan pelayanan Kartu Kuning (AK1) Kartu Kuning (AK 1) yang bersifat terbuka, dan bertanggungjawab. Proses pengembangan setiap bentuk pelayanan Kartu Kuning (AK1) Kartu Kuning (AK 1) harus diawali dengan perumusan visi dan misi yang tepat. Sebuah pelayanan Kartu Kuning (AK1) tidak akan pernah menjadi pelayanan 
Kartu Kuning (AK1) prima jika tidak akuntabel, yaitu terbuka dan bertanggung jawab. Menurut Kepala Dinas Tenaga Kerja dan Transmigrasi Kabupaten Sintang, prinsip pelayanan Kartu Kuning (AK1) di Dinas Sosial, Tenaga Kerja dan Transmigrasi Kabupaten Sintang adalah mengutamakan pencari kerja, dengan melakukan perbaikan yang berkelanjutan dan memberdayakan pencari kerja. Dikatakan Kepala Dinas Tenaga Kerja dan Transmigrasi Kabupaten Sintang: Prosedur pelayanan Kartu Kuning (AK1) telah di susun demi kemudahan dan kenyamanan pencari kerja, sekaligus untuk memperlancar pekerjaan yang menjadi tugas pokok dan fungsi Dinas Tenaga Kerja dan Transmigrasi Kabupaten Sintang. Pelayanan Kartu Kuning (AK1) di Dinas Tenaga Kerja dan Transmigrasi Kabupaten Sintang dilihat sebagai sebuah sistem, yaitu tatanan yang memadukan hasil-hasl kerja dan berbagai unit dalam organisasi. Perpaduan ini harus terlihat sebagai sebuah proses pelayanan Kartu Kuning (AK1) yang berlangsung dengan tertib dan lancar di mata para pencari kerja. Jika perpaduan ini sungguh baik, pencari kerja bahkan tidak pernah merasakan bahwa mereka sebenarnya telah berhadapan dengan beberapa unit yang berbeda. Dari segi disain pengembannya, setiap pelayanan Kartu Kuning (AK1) selayakya memiliki prosedur yang memungkinkan perpaduan hasil kerja ini dapat mencapai batas maksimum.

Sedangan untuk pencari kerja yang dapat disalurkan 143 orang baik pekerjaan formal maupun informal dengan kualifikasi menurut pendidikan sebagai berikut : SD: 20 orang, SLTP: 28 orang, SLTA: 24 orang, D I / D II, dan D III: 25 orang dan D IV / S1: 46 orang. Sebaik apapun disain dan prosedur sebuah pelayanan Kartu Kuning (AK1), akhirnya tetap para petugas pelayanan Kartu Kuning (AK1) yang harus berhadapan muka secara langsung dengan para pencari kerja. Saatsaat terjadinya transaksi antar manusia seperti ini sangat berharga. Penilaian pencari kerja terhadap mutu sebuah layanan sebagian besar terjadi ketika mereka bertemu muka langsung dengan petugas pelayanan Kartu Kuning (AK1). Meskipun sarana dan prasarana pelayanan Kartu Kuning (AK1) sering dijadikan ukuran mutu oleh para pencari kerja, namun ukuran utama penilaian tetap sikap dan perilaku pelayanan Kartu Kuning (AK1) yang ditampilkan oleh para petugas. Sikap dan perilaku yang baik oleh petugas sering dapat menutup kekurangan dalam hal sarana dan prasarana.

Pencari kerja pada dasarnya juga belajar mengenali kebutuhan dirinya dari proses pelayanan Kartu Kuning (AK1). Semakin baik mutu pelayanan Kartu Kuning (AK1) akan menghasilkan pencari kerja yang semakin sulit untuk dipuaskan, karena tuntutannya juga semakin tinggi dan kebutuhannya semakin meluas serta beragam. Memberdayakan pencari kerja berarti menawarkan jenis-jenis layanan yang dapat digunakan sebagai sumber daya atau perangkat tambahan oleh pencari kerja untuk menyelesaikan persoalan hidupnya sehari-hari. Kelebihan dari daur kegiatan pencari kerja adalah kemampuannya untuk menggambarkan secara menyeluruh semua kegiatan pencari kerja yang perlu dan yang mungkin harus mereka jalankan sebagai akibat dari kreativitas pelayanan Kartu Kuning (AK1) yang kita ciptakan. Baik itu sebelum kita layani sampai sesudah kita layani. Dengan demikian kita dapat menilai akibat dari kreativitas kita sendiri. Menurut Kepala Dinas Tenaga Kerja dan Transmigrasi Kabupaten Sintang, rancangan bagi keseluruhan proses pelayanan Kartu Kuning (AK1) harus didasarkan pada kegiatan pencari kerja, seperti yang sudah kita ciptakan dengan menggunakan daur kegiatan pencari kerja seperti di atas. Hal seperti ini disebut dengan pendekatan mulai dari hasil akhir. Dengan pendekatan ini kita menyiapkan rancangan proses pelayanan Kartu Kuning (AK1) secara bertahap mengikuti langkah-langkah antara lain dengan menetapkan bentuk dari mutu layanan yang akan diterima oleh para pencari kerja, dengan sepenuhnya mengacu pada kegiatan mereka.

Penduduk usia kerja biasanya dikelompokkan ke dalam angkatan kerja dan bukan tenaga kerja. Konsep ini diadopsi dari negara yang sudah maju yang mempunyai ciri ekonomi dan tenaga kerja yang berbeda dengan negara yang sedang berkembang. Selain itu, penyediaan tenaga kerja yang sifatnya terbatas karena tidak semua penduduk merupakan tenaga kerja, dalam hal ini hanya penduduk yang telah mencapai umur minimum tertentu baru bisa dianggap sebagai tenaga kerja potensial atau angkatan kerja. Di Indonesia, hanya mereka yang telah mencapai usia 10 tahun ke atas yang dianggap sebagai angkatan kerja dan tidak semua angkatan kerja terlibat dalam kegiatan ekonomi (bekerja). Jumlah angkatan kerja dalam satu daerah pada suatu waktu tertentu tergantung dari jumlah penduduk usia kerja, semakin besar penduduk usia kerja maka akan semakin besar pula jumlah angkatan kerja. Standar pelayanan Kartu Kuning (AK1) umumnya memuat hal-hal seperti berikut: visi dan misi pelayanan Kartu Kuning (AK1), spesifikasi pencari kerja, prosedur pelayanan Kartu Kuning (AK1), pengawasan dan pengendalian mutu, lampiran yang memuat denah lokasi, formulir, hasil kesepakatan, dll. Pernyataan visi dan misi dalam standar pelayanan Kartu Kuning (AK1) dimaksudkan untuk menunjukkan hakekat pelayanan Kartu Kuning (AK1) yang menjiwai semua aspek dalam tatanan pelayanan Kartu Kuning (AK1).

Bagi petugas pelayanan Kartu Kuning (AK1), pernyataan visi diharapkan mampu menggugah rasa kebanggaan dan semangat kejuangan mereka dalam bertugas. Kegiatan pelayanan Kartu Kuning (AK1) dilaksanakan 
bukan hanya karena tugas pekerjaan apa saja, melainkan ada sesuatu yang sangat bermakna bagi martabat mereka sendiri sebagai manusia. Sedangkan pernyataan misi diharapkan dapat berperan sebagai koridor sejauh manakah mereka dapat melakukan kreativitas dan inovasi. Bagi para pencari kerja, pernyataan visi mencerminkan ukuran normatif sejauh manakah pelayanan Kartu Kuning (AK1) itu akan membela kepentingan mereka. Sedangkan dari pernyataan misi pencari kerja dapat mengetahui ciri-ciri pelayanan Kartu Kuning (AK1) yang akan diperoleh. Jenis-jenis pelayanan Kartu Kuning (AK1) yang akan disajikan kepada para pencari kerja harus dinyatakan secara eksplisit dan rinci, meliputi pelayanan Kartu Kuning (AK1) utama, pendukung, dan tambahan. Jika terdapat perbedaan jenis pelayanan Kartu Kuning (AK1) eksternal dan pelayanan Kartu Kuning (AK1) internal juga harus dinyatakan secara tegas. Prosedur pelayanan Kartu Kuning (AK1) merupakan bagian yang paling penting dari standar pelayanan Kartu Kuning (AK1). Penulisannya harus sangat rinci, dan biasanya meliputi hal-hal sebagai berikut: diagram alur kegiatan pencari kerja serta prosedur persiapan pelayanan Kartu Kuning (AK1), yaitu hal-hal rutin apa saja yang perlu dilakukan petugas sebelum memulai pelayanan Kartu Kuning (AK1) nya sehari-hari bagi pencari kerja. Untuk keperluan ini, hasil-hasil kesepakatan koordinasi antar unit pelaksana dapat dijadikan bahan acuan.

Prosedur semacam ini perlu disusun untuk semua kegiatan pelayanan Kartu Kuning (AK1) bagi pencari kerja. Prosedur pelayana harus cukup rinci, dan biasanya memuat beberapa hal penting : berkas/persyaratan yang harus dilengkapi pencari kerja, lokasi tempat penyelenggaraan pelayanan Kartu Kuning (AK1), petugas yang melayani, sikap petugas pelayanan Kartu Kuning (AK1), berkas/bukti pelayanan Kartu Kuning (AK1) yang harus diterima pencari kerja, rincian tarif pelayanan Kartu Kuning (AK1), dan tata cara pembayaran, waktu/hari pelayanan Kartu Kuning (AK1), dan lain semacamnya.Prosedur penutupan pelayanan Kartu Kuning (AK1), yaitu hal-hal rutin apa saja yang perlu dilakukan petugas dalam mengakhiri tugas pelayanan Kartu Kuning (AK1) nya seharihari. Sebagai contoh:

Dalam standar pelayanan Kartu Kuning (AK1) harus secara tegas dinyatakan ukuran mutu pelayanan Kartu Kuning (AK1) yang akan diperoleh para pencari kerja, dan tata cara untuk mengawasi serta mengendalikan mutu pelayanan Kartu Kuning (AK1) tersebut. Pernyataan mutu pelayanan Kartu Kuning (AK1) yang akan diperoleh para pencari kerja. Pernyataan ini perlu disampaikan secara terbuka kepada para pencari kerja melalui kemasan-kemasan khusus seperti brosur, iklan, siaran pers, dll. Pernyataan mutu pelayanan Kartu Kuning (AK1) dapat terdiri atas beberapa bagian, antara lain pernyataan mutu layanan, yaitu spesifikasi layanan-layanan yang akan diterima oleh pencari kerja. Pengawasan mutu pelayanan Kartu Kuning (AK1) diartikan sebagai semua upaya untuk memantau dan mengukur mutu pelayanan Kartu Kuning (AK1). Pengawasan mutu terdiri atas 2 bagian diantaranya adalah pengawasan ekternal oleh pencari kerja untuk memantau dan mengukur mutu pelayanan Kartu Kuning (AK1) apakah sudah sesuai dengan harapan pencari kerja. Untuk keperluan ini, dapat disediakan kemudahan-kemudahan antara lain : loket khusus untuk menampung keluhan dari pencari kerja secara langsung, kotak saran, saluran telepon khusus. Tata cara pengawasan eksternal ini juga harus diwujudkan menjadi prosedur tetap. Pengawasan internal oleh para petugas pelayanan Kartu Kuning (AK1) terhadap ketertiban dan kelancaran kegiatan pelayanan Kartu Kuning (AK1) menurut prosedur yang telah ditetapkan. Apabila langkah koordinasi dilakukan dengan baik, dan prosedur pelayanan Kartu Kuning (AK1) ditulis dengan cermat, maka tata cara pengawasan internal ini tentu sudah menjadi bagian integral dari prosedur tetap pelayanan Kartu Kuning (AK1). Harapan pencari kerja sangat dipengaruhi oleh kebutuhan pribadinya, penilaiannya terhadap mutu pelayanan Kartu Kuning (AK1) setelah saling berkomunikasi dengan pencari kerja lain, pengalaman pribadinya sebagai pencari kerja di masa-masa yang lalu dan janji-janji pelayanan Kartu Kuning (AK1) yang disampaikan oleh petugas pemasaran. Faktor-faktor ini perlu digali dengan evaluasi pelayanan Kartu Kuning (AK1). Meskipun jarang terjadi, hasil analisis mungkin menunjukkan bahwa pencari kerja telah merasa puas dengan mutu pelayanan Kartu Kuning (AK1) yang mereka terima. Jika hal semacam ini terjadi, maka kita melanjutkan kelangkah pembaharuan disain lagi namun dengan titik perhatian untuk dapat menemukan disain yang lebih antisipatif terhadap perkembangan kebutuhan pencari kerja di masa datang. Mengukur tingkat pemahaman petugas pelayanan Kartu Kuning (AK1) terhadap harapan pencari kerja. Jika ternyata tingkat pemahaman para manajer masih rendah, maka berarti pelayanan Kartu Kuning (AK1) kita memerlukan pembaharuan disain lagi agar lebih dapat memenuhi harapan pencari kerja. Sebaliknya, jika para petugas sudah dapat memahami harapan pencari kerja, maka dapat melanjutkan dengan meneliti ulang konsistensi rancangan pelayanan Kartu Kuning (AK1) yang pernah di susun sebelumnya. Dengan menelusuri pertanyan-pertanyaan di atas niscaya akan dapat ditemukan titik-titik lemah dalam disain pelayanan Kartu Kuning (AK1) kita, dan dapat disempurnakan seperlunya. Namun jika uji konsistensi ini ternyata memberikan hasil yang baik, maka kita dapat melanjutkan dengan langkah menilai tingkat kepatuhan petugas pelayanan Kartu Kuning (AK1) terhadap standar pelayanan Kartu Kuning (AK1) dalam melaksanakan kegiatan pelayanan Kartu Kuning (AK1)nya sehari-hari. 
Hambatan psikologis yang umum dijumpai adalah depresi, sulit konsentrasi, tidak akur dengan teman sekerja, pasif-agresif, kurang motivasi, kurang percaya diri, penuh kecurigaan kepada orang lain, merasa tidak aman, merasa dikucilkan, emosinya tidak stabil, dan lain semacamnya. Tindakan psikologis dapat berupa pendampingan, konsultasi psikologis, atau psikoterapi. Kadang kala dijumpai petugas mengalami gangguan kepribadian yang menyebabkan mereka memang tidak dapat berfungsi efektif sebagai petugas pelayanan Kartu Kuning (AK1). Untuk petugas semacam ini harus segera digantikan dengan yang lain. Jika ternyata petugas menunjukkan tingkat kepatuhan yang tinggi terhadap standar pelayanan Kartu Kuning (AK1), maka meneliti dampak kegiatan pemasaran terhadap pembentukan harapan pencari kerja. Tanpa sengaja, kadang kala kegiatan pemasaran telah mengobral janji-janji yang berlebihan kepada para calon pencari kerja kita. Penggunaan media atau teknik komunikasi yang kurang tepat juga dapat menimbulkan salah pengertian pada pihak calon pencari kerja, dan menimbulkan harapan yang berlebihan. Satu hal yang pasti, jika ternyata sama sekali tidak ada kegiatan pemasaran, maka harapan pencari kerja akan terbentuk secara liar dan tentunya sangat sulit untuk dipenuhi.

Salah satu kewenangan wajib yang dilaksanakan oleh daerah Kabupaten/Kota adalah di bidang ketenagakerjaan. Oleh karena itu, dari kewenangan wajib ini, daerah memiliki peluang dan sekaligus tantangan dalam penanganan masalah ketenagakerjaan di daerah. Dikatakan peluang, karena melalui kewenangan yang dimiliki daerah dapat membuat kebijakan, program dan strategi yang baik, tepat dan akurat serta menyentuh persoalan mendasar yang ada di daerah tentang ketenagakerjaan. Sedangkan sebagai tantangan, persoalan ketenagakerjaan di daerah adalah problem yang rumit dan kompleks sehingga dibutuhkan sumber daya yang cukup besar dalam penanganannya.

Jumlah Kartu Kuning (AK1) yang diterbitkan oleh Dinas Tenaga Kerja dan Transmigrasi Kabupaten Sintang Tahun 2019 mencapai 1.343 orang dengan kualisasi pendidikan SD sebanyak 51 orang $(3,79 \%)$, SMP sebanyak 110 orang $(8,19 \%)$, SMA sebanyak 565 orang (42,06\%), D I / D II, dan D III sebanyak 252 orang $(18,76 \%)$, D IV / S1 sebanyak 365 orang (27,17\%). Prinsip Pelayanan Kartu Kuning (AK1) Pada Dinas Tenaga Kerja dan Transmigrasi Kabupaten Sintang belum sepenuhnya dapat diterapkan. Begitupula dengan Unsur-Unsur Pelayanan Kartu Kuning (AK1) Pada Dinas Sosial, Tenaga Kerja dan Transmigrasi Kabupaten Sintang belum optimal dilaksanakan.

Standar pelayanan Kartu Kuning (AK1) Di Dinas Sosial, Tenaga Kerja dan Transmigrasi Kabupaten Sintang berupa visi dan misi pelayanan Kartu Kuning (AK1), spesifikasi pencari kerja, prosedur pelayanan Kartu Kuning (AK1), pengawasan dan pengendalian mutu, serta lampiran yang memuat denah lokasi, formulir, hasil kesepakatan dan sebagainya belum dibuat. Padahal, bagi petugas pelayanan Kartu Kuning (AK1), pernyataan visi diharapkan mampu menggugah rasa kebanggaan dan semangat kejuangan mereka dalam bertugas. Kegiatan pelayanan Kartu Kuning (AK1) dilaksanakan bukan hanya karena tugas pekerjaan apa saja, melainkan ada sesuatu yang sangat bermakna bagi martabat mereka sendiri sebagai manusia. Sedangkan pernyataan misi diharapkan dapat berperan sebagai koridor sejauh manakah mereka dapat melakukan kreativitas dan inovasi. Bagi para pencari kerja, pernyataan visi mencerminkan ukuran normatif sejauh manakah pelayanan Kartu Kuning (AK1) itu akan membela kepentingan mereka. Sedangkan dari pernyataan misi pencari kerja dapat mengetahui ciri-ciri pelayanan Kartu Kuning (AK1) yang akan diperoleh. Persiapan Pelayanan Kartu Kuning (AK1) Petugas Loket Di Dinas Tenaga Kerja dan Transmigrasi Kabupaten Sintang belum begitu baik. Sedangkan Perilaku Pelayanan Kartu Kuning (AK1) Terhadap Pencari kerja Di Dinas Tenaga Kerja dan Transmigrasi Kabupaten Sintang cukup baik. Baku Mutu Sarana/ Prasarana Pelayanan Kartu Kuning (AK1) seperti Ruang Tunggu, Peralatan, Brosur, Loket Pendaftaran, Loket Pembayaran di Dinas Tenaga Kerja dan Transmigrasi Kabupaten Sintang belum tersedia secara lengkap. Evaluasi Pelayanan diperlukan untuk menilai apakah Pelayanan kita sudah sesuai dengan Harapan Pelanggan atau belum. Langkah-Langkah Evaluasi Pelayanan Kartu Kuning (AK1) Di Dinas Tenaga Kerja dan Transmigrasi Kabupaten Sintang belum sepenuhnya dapat dilaksanakan. Padahal dengan evaluasi, dapat ditemukan titik-titik lemah dalam disain pelayanan Kartu Kuning (AK1), dan dapat disempurnakan seperlunya.

Komposisi Pegawai Dinas Tenaga Kerja dan Transmigrasi Kabupaten Sintang Berdasarkan Kualifikasi Pendidikan Tahun 2010 cukup tinggi. Mereka yang berpendidikan Pascasarjana, Sarjana dan Diploma cukup banyak. Komposisi Pegawai Dinas Tenaga Kerja dan Transmigrasi Kabupaten Sintang Berdasarkan Pangkat/Golongan Ruang Tahun 2010 sebagian besar adalah Penata/ Golongan III. Komposisi Pegawai Dinas Sosial, Tenaga Kerja dan Transmigrasi Kabupaten Sintang Berdasarkan Eselonering Tahun 2010 sebagian besar adalah pada eselon IV. Kompetensi pegawai pada eselon IV antara lain adalah dapat mengoperasionalkan sistem dan prosedur kerja yang berkaitan dengan pelaksanaan kebijakan dan tugas instansi, mampu melaksanakan prinsip-prinsip good governance dalam manajemen pemerintahan dan pembangunan, mampu melaksanakan kebijakan pelayanan prima, mampu mengambil keputusan yang tepat sesuai dengan kewenangan dan prosedur yang berlaku di unit 
kerja, mampu menerapkan prinsip dan teknik perencanaan, pengendalian, pengawasan, dan evaluasi kinerja unit organisasi, serta mampu menerapkan teknik pengelolaan, penyampaian informasi dan pelaporan yang efektif dan efisien. Kompetensi tersebut tentunya sangat diperlukan dalam Pelaksanaan Administrasi Pelayanan Kartu Kuning (AK1) pada Dinas Sosial, Tenaga Kerja Dan Transmigrasi Kabupaten Sintang.

Anggaran pada Dinas Tenaga Kerja Dan Transmigrasi Kabupaten Sintang untuk mendukung program dan kegiatan dalam rangka penyelenggaraan urusan Ketenagakerjaan khususnya Pelaksanaan Administrasi Pelayanan Kartu Kuning (AK1) tahun 2019 cukup memadai. Pada Tahun 2019, Program dan kegiatan tersebut adalah Program Peningkatan Kesempatan Kerja dengan anggaran sebesar Rp106.733.900,00 dan realisasi penggunaan dana sebesar Rp94.854.150,00 atau 88,87\%, yang didukung oleh 2 (dua) kegiatan, yaitu: (1) Penyusunan Informasi Bursa Tenaga Kerja, dan (2) Pengembangan Kelembagaan Produktivitas dan Pelatihan Kewirausahaan. Pada Tahun 2020 jumlahnya menurun yaitu untuk Program Peningkatan Kesempatan Kerja dengan anggaran sebesar Rp47.324.300,00 yang didukung oleh 1 (satu) kegiatan yaitu: Penyebarluasan informasi bursa tenaga kerja. Pada hakikatnya untuk dapat menjalankan Administrasi Pelayanan Kartu Kuning (AK1) Kartu Kuning (AK 1) Pada Dinas Tenaga Kerja Dan Transmigrasi Kabupaten Sintang memerlukan dukungan peralatan/barang yang memadai. Secara umum sarana dan prasarana yang digunakan dalam melaksanakan kegiatan Administrasi Pelayanan Kartu Kuning (AK1) Kartu Kuning (AK 1) Pada Dinas Tenaga Kerja Dan Transmigrasi Kabupaten Sintang masih belum memadai, sarana dan prasarana yang ada merupakan hasil pengadaan pemerintah Kabupaten Sintang.

\section{KESIMPULAN DAN SARAN}

Bentuk Pelaksanaan Administrasi Pelayanan Kartu Kuning (AK1) Kartu Kuning (AK 1) Pada Dinas Tenaga Kerja Dan Transmigrasi Kabupaten Sintang yaitu Desain Pelayanan Kartu Kuning (AK1) belum sepenuhnya dapat diterapkan. Begitupula dengan Unsur-Unsur Pelayanan Kartu Kuning (AK1) belum optimal dilaksanakan. Standar pelayanan Kartu Kuning (AK1) Di Dinas Tenaga Kerja dan Transmigrasi Kabupaten Sintang berupa visi dan misi pelayanan Kartu Kuning (AK1), spesifikasi pencari kerja, prosedur pelayanan Kartu Kuning (AK1), pengawasan dan pengendalian mutu, serta lampiran yang memuat denah lokasi, formulir, hasil kesepakatan dan sebagainya belum dibuat. Baku
Mutu Sarana/Prasarana Pelayanan Kartu Kuning (AK1) seperti Ruang Tunggu, Peralatan, Brosur, Loket Pendaftaran, Loket Pembayaran di Dinas Sosial, Tenaga Kerja dan Transmigrasi Kabupaten Sintang belum tersedia secara lengkap. LangkahLangkah Evaluasi Pelayanan Kartu Kuning (AK1) Di Dinas Tenaga Kerja dan Transmigrasi Kabupaten Sintang belum sepenuhnya dapat dilaksanakan. Faktor-Faktor Yang Mempengaruhi Pelaksanaan Administrasi Pelayanan Kartu Kuning (AK1) Kartu Kuning (AK 1) Pada Dinas Sosial, Tenaga Kerja Dan Transmigrasi Kabupaten Sintang berdasarkan Kualitas Dan Kuantitas Aparatur berdasarkan Kualifikasi Pendidikan Tahun 2020 cukup tinggi. Mereka yang berpendidikan Pascasarjana, Sarjana dan Diploma cukup banyak. Komposisi Pegawai Berdasarkan Pangkat/Golongan Ruang sebagian besar adalah Penata/Golongan III. Komposisi Pegawai berdasarkan Eselonering Tahun 2020 sebagian besar adalah pada eselon IV. Kompetensi pegawai khususnya eselon IV dan staf sangat diperlukan dalam Pelaksanaan Administrasi Pelayanan Kartu Kuning (AK1) pada Dinas Sosial, Tenaga Kerja Dan Transmigrasi Kabupaten Sintang. Anggaran pada Dinas Sosial, Tenaga Kerja Dan Transmigrasi Kabupaten Sintang untuk mendukung program dan kegiatan dalam rangka penyelenggaraan urusan Ketenagakerjaan khususnya Pelaksanaan Administrasi Pelayanan Kartu Kuning (AK1) tahun 2019 cukup memadai. Secara umum sarana dan prasarana yang digunakan dalam melaksanakan kegiatan Administrasi Pelayanan Kartu Kuning (AK1) Kartu Kuning (AK 1) Pada Dinas Tenaga Kerja Dan Transmigrasi Kabupaten Sintang masih belum memadai, sarana dan prasarana yang ada merupakan hasil pengadaan pemerintah Kabupaten Sintang. Pelaksanaan Administrasi Pelayanan Kartu Kuning (AK1) Kartu Kuning (AK1) pada Dinas Tenaga Kerja Dan Transmigrasi Kabupaten Sintang yaitu berupa Desain Pelayanan Kartu Kuning (AK1) diharapkan sepenuhnya dapat diterapkan. Begitu pula dengan Unsur-Unsur Pelayanan Kartu Kuning (AK1) diharapkan dapat dilaksanakan. Selain itu, diharapan dapat disusun Standar pelayanan Kartu Kuning (AK1) berupa visi dan misi pelayanan Kartu Kuning (AK1), spesifikasi pencari kerja, prosedur pelayanan Kartu Kuning (AK1), pengawasan dan pengendalian mutu, serta lampiran yang memuat denah lokasi, formulir, hasil kesepakatan dan sebagainya. Baku Mutu Sarana/Prasarana Pelayanan Kartu Kuning (AK1) seperti Ruang Tunggu, Peralatan, Brosur, Loket Pendaftaran, Loket Pembayaran diharapkan dapat disediakan sesuai standar yang diperlukan. Sarana dan prasarana yang digunakan dalam melaksanakan kegiatan Administrasi Pelayanan Kartu Kuning (AK1) diharapkan dapat ditingkatkan. 


\section{DAFTAR PUSTAKA}

Dipohusodo. 1996. Evaluasi Proyek. Jakarta: Gunung Agung.

Dunn, WN. 2000. Pengantar Analisis Kebijakan Publik. Yogyakarta: Gajah Mada Universiti Press.

Effendi, S. 1993. Strategi Administrasi dan Pemerataan Akses padaPelayanan Publik Indonesia. Laporan Hasil Penelitian. Yogyakarta: Fisipol UGM.

Islamy,M.I. 1999. Reformasi Pelayanan Publik, Makalah Pelatihan Strategi Pembangunan Sumber Manusia Aparatur Pemerintah Daerah dalam Era Globalisasi, di Kabupaten Daerah Tingkat II Trenggalek.
Mohamad. I. 2003. Aktualisasi Pelayanan Prima Dalam Kapasitas PNS sebagai Abdi Negara dan Abdi Masyarakat. Jakarta: LAN

Moenir, H.AS. 1998. Manajemen Pelayanan Umum di Indonesia. Cetakan III. Jakartal Bumi Aksara.

Sutopo dan Sugiyanti.1998. Pelayanan Prima. Jakarta: Lembaga Administrasi Negara RI.

Suryono, A. 2009. Budaya Birokrasi Pelayanan Publik. Jakarta: Universitas Terbuka. 